Int. J. Electrochem. Sci., 12 (2017) $2658-2668$

International Journal of

ELECTROCHEMICAL

SCIENCE

www.electrochemsci.org

\title{
A High Sensitive Electrochemical Avian Influenza Virus H7 Biosensor Based on CNTs/MoSx Aerogel
}

\author{
Jingzhi Tian*, Dandan Wang, Yongjie Zheng, Tao Jing \\ Schoole of Chemistry and Engineering, Qiqihar University, Qiqihar, 161006, China; \\ *E-mail: zyj1964@163.com \\ doi: $10.20964 / 2017.04 .30$
}

Received: 30 October 2016 / Accepted: 8 February 2017 / Published: 12 March 2017

\begin{abstract}
The three-dimensional $\mathrm{CNTs} / \mathrm{MoS}_{\mathrm{x}}$ aerogel was successfully prepared via solvothermal method. The favourable combination of $\mathrm{MoS}_{2}$ material and 3D conductive networks of CNTs aerogel have created a sufficient active site for fast charge transport. The electrochemical immunosensor with a sandwichtype immunoassay using $\mathrm{CNTs} / \mathrm{MoS}_{\mathrm{x}}$ aerogel as trace labels was constructed. Avian influenza virus H7 (AIV H7) could be quantified sensitively using the proposed immunosensor. The immunoassay was carried out on the modified surface of $\mathrm{CNTs} / \mathrm{MoS}_{\mathrm{x}}$ with the adsorption of $\mathrm{H} 7$-polyclonal antibodies (PAb-CNTs/MoS 2 ). The immunosensor with PAb-CNTs/MoS ${ }_{\mathrm{x}}$ as detection antibodies have demonstrated a linear detection range of $1-25 \mathrm{ng} / \mathrm{mL}$ with the low detection limit of $0.43 \mathrm{ng} / \mathrm{mL}$.
\end{abstract}

Keywords: CNTs aerogel; Molybdenum sulfide; Electrochemical immunosensor; Avian influenza virus $\mathrm{H} 7$

\section{$\underline{\text { FULL TEXT }}$}

(C) 2017 The Authors. Published by ESG (www.electrochemsci.org). This article is an open access article distributed under the terms and conditions of the Creative Commons Attribution license (http://creativecommons.org/licenses/by/4.0/). 